\title{
Regeneration in White Sea sponge Leucosolenia complicata (Porifera, Calcarea)
}

\author{
A.V. Ereskovsky ${ }^{1,2}$, A.I. Lavrov ${ }^{3,4}$, F.V. Bolshakov ${ }^{3}$, D.B. Tokina ${ }^{1}$ \\ ${ }^{1}$ Institut Méditerranéen de Biodiversité et d'Ecologie marine et continentale (IMBE), Aix Marseille \\ Université, CNRS, IRD, Marseille, France.E-mail: aereskovsky@mail.ru \\ ${ }^{2}$ Dept. Embryology, Faculty of Biology, Saint-Petersburg State University, Saint-Petersburg, \\ Russia. \\ ${ }^{3}$ Pertsov White Sea Biological Station, Biological Faculty, Moscow State University M.V. Lomonos- \\ ov, Moscow, Russia. \\ ${ }^{4}$ Koltzov Institute of Developmental Biology of Russian Academy of Sciences, Russia, Moscow.
}

\begin{abstract}
Sponges (phylum Porifera) possess the remarkable regenerative abilities and great diversity of the regeneration mechanisms. The current study dealt with the regeneration of calcareous sponge Leucosolenia complicata. Two types of experiments on $L$. complicata regeneration were performed: 1) the regeneration of the body wall, and 2) the regeneration of the amputated oscular tube. We have combined in vivo light microscopy and histological studies to reveal morphogenetic mechanisms and determine the cell types involved in the reparative regeneration in this sponge. The wound healing followed by complete restoration of lost body parts have been observed in both types of the experiments. The regeneration in Leucosolenia has a mode in which lost body parts are replaced by the remodeling of the remaining tissue. Epithelial morphogenesis, mainly spreading (flattening) and fusion of exo- and endopinacoderm sheets accompanied by the transdifferentiation of the choanocytes to the endopinacocytes was found to be the key morphogenetic process during regeneration in this species. The epithelial nature of the regeneration in Leucosolenia makes it similar to the regeneration in homoscleromorphs sponges and Eumetazoans. How to cite this article: Ereskovsky A.V., Lavrov A.I., Bolshakov F.V., Tokina D. 2017. Regeneration in White Sea sponge Leucosolenia complicata (Porifera, Calcarea) // Invert. Zool. Vol.14. No.2. P.108-113. doi: 10.15298/invertzool.14.2.02
\end{abstract}

KEY WORDS: regeneration, epithelial morphogenesis, sponge, Leucosolenia.

\section{Регенерация беломорской губки Leucosolenia complicata (Porifera, Calcarea)}

\author{
А.В. Ересковский ${ }^{1,2}$, А.И. Лавров ${ }^{3,4}$, Ф.В. Большаков ${ }^{3}$, Д.Б. Токина ${ }^{1}$ \\ ${ }^{1}$ Средиземноморский институт биоразнообразия и экологии, НЦНИ, университет Экс- \\ Марсель, ИРД, Марсель, Франиия. E-mail: aereskovsky@mail.ru \\ ${ }^{2}$ Биологический факультет Санкт-Петербургского государственного университета, C- \\ Петербург, Россия. \\ ${ }^{3}$ Беломорская биологическая станция им. Н.А. Периова, Биологический факультет, МГУ им. \\ М.В. Ломоносова, Москва, Россия. \\ ${ }^{4}$ Институт биологии развития им. Н.К. Кольиова РАН, Москва, Россия.
}

РЕЗЮМЕ: Губки (тип Porifera) обладают значительными регенеративными способностями и большим разнообразием механизмов регенерации. Настоящая работа 
посвящена исследованию регенерации известковой губки Leucosolenia complicata. Были проведены два типа экспериментов по регенерации L. complicata: 1) регенерация стенки тела и 2) регенерация отрезанных оскулярных трубок. Мы использовали прижизненные наблюдения и гистологические исследования, чтобы выявить морфогенетические механизмы и определить клеточные источники, принимающие участие репаративной регенерации этой губки. Заживление раны заканчивается полным восстановлением потерянных частей тела в обоих типах экспериментов. В регенерации L. complicata потерянные части тела восстанавливаются благодаря перераспределению оставшихся тканей. Основным механизмом регенерации Leucosolenia является эпителиальный морфогенез, в основном распространение (уплощение) и слияние экзо- и эндопинакодермы, которые сопровождаются трансдифференцировкой хоаноцитов в эндопинакоциты. Эпителиальный характер регенерации L. complicata сближает ее с регенерации губок из класса Homoscleromorpha и высших многоклеточных животных (Eumetazoa).

Как цитировать эту статью: Ereskovsky A.V., Lavrov A.I., Bolshakov F.V., Tokina D. 2017. Regeneration in White Sea sponge Leucosolenia complicata (Porifera, Calcarea) // Invert. Zool. Vol.14. No.2. P.108-113. doi: 10.15298/invertzool.14.2.02

КЛЮЧЕВЫЕ СЛОВА: регенерация, эпителиальные морфогенезы, губки, Leucosolenia.

\section{Introduction}

The morphological and cellular plasticity of sponges (phylum Porifera) allows them to adapt to the variations in the environmental conditions. Therefore, they often dominate the benthic communities in the diverse marine and freshwater ecosystems from tropical to polar regions. The ecological success of the sponges is partially a result of their rapid regeneration capacity enabling them to recover from damages (Ayling, 1983; Luter et al., 2012; Wulff, 2013). Sponges are known to possess remarkable regenerative and reconstitutive abilities ranging from the re-building of a functional body from dissociated cells to wound healing or body part regeneration (Korotkova, 1997).

Sponges show big diversity of the regeneration mechanisms (Alexander et al., 2015; Borisenko et al., 2015; Ereskovsky et al., 2015; Lavrov, Kosevich, 2016). As an ancient animal lineage, sponges are important models in studies aimed at understanding of the evolution of animal regeneration mechanisms. For this purpose, it is necessary to expand the objects from different clades and with different body structure.
Leucosolenia complicata (Montagu, 1818) (class Calcarea) is a common species in littoral habitats along the North European coasts from the English Channel to the White Sea (Rapp, 2015), and is accessible throughout the year. This species has been successfully used for different experiments concerning the study of restoration morphogenesis (Jones, 1957; Korotkova, 1961, 1969). It was showed their quick wound healing and high regeneration capacity after different surgical interventions indicating that Leucosolenia is a convenient model for sponge regeneration investigations.

The present study is aimed at revealing morphogenetic mechanisms and determining the cell types involved in the reparative regeneration in White Sea Leucosolenia complicata using in vivo light microscopy and histological studies. Our study demonstrates that main mechanism of reparative regeneration in this species is epithelial morphogenesis by spreading of cell layers that accompanied by choanocytes transdifferentiation.

\section{Material and methods}

Leucosolenia complicata is an asconoid sponge with the body formed by the anastomos- 
ing hollow tubes with the internal cavities completely lined with choanocytes, and external surface covered with the layer of the flat and Tshaped exopinacocytes. The narrow space inbetween the exopinacoderm and choanoderm is occupied by the mesohyl - complex tissue comprising abundant ECM, rare wandering amoeboid cells, calcium carbonate spicules and symbiotic bacteria.

The specimens of L. complicata were collected in the environs of Pertsov White Sea Biological Station of Lomonosov Moscow State University (Kandalakshsky Bay, White Sea) $\left(66^{\circ} 34^{\prime} \mathrm{N}, 33^{\circ} 08^{\prime} \mathrm{E}\right)$ from the upper subtidal zone $(0-2 \mathrm{~m})$ at the low-tide. Prior the experiments the sponges were maintained in the 1001 aquarium with biological filters and natural sea water at temperature $6-10{ }^{\circ} \mathrm{C}$ no longer than 4 days.

Two types of experiments on L. complicata regeneration were performed: 1) the regeneration of the body wall, and 2) the regeneration of the amputated oscular tube. In the former, case the small square part (approximately $0.5 \times 0.5$ $\mathrm{mm}$ ) of body wall were excised at the basis of the oscular tube. In the latter, case the oscular tubes were amputated from sponges and the regeneration of basal parts of such amputated oscular tube was observed. Several oscular tubes were amputated from a single sponge. All surgical operations were done manually under a dissecting microscope using Castroviejo scissors. A total of 36 sponges were used in the experiments. Twenty-seven individuals were used in the body wall regeneration experiments. Twenty-seven oscular tubes obtained from nine individuals were used in the oscular tube regeneration experiments.

The specimens were maintained in Petri dishes with $0.22 \mu \mathrm{m}$-filtered sea water (FSW) at temperature $10-11^{\circ} \mathrm{C}$ after the surgical operations. The half of FSW were changed every 12 h. At 3, 6, 12, 18, 24, 36, 48, 72 and 96 hours post operation (hpo) specimens were inspected and photographed using the stereomicroscope Leica M165FC (Leica, Germany) equipped with the digital camera Leica DFC 320 and Leica LAS Store and Recall v.3.6 software. The fixa- tion of the specimens for the histological studies by $2.5 \%$ glutaraldehyde (Ted Pella, Inc., USA) on $0.2 \mathrm{M}$ Millonig's phosphate buffer ( $\mathrm{pH}$ 7.4) (Millonig, 1964) were performed at the same time points. After the fixation, the spicules were removed from specimens by treatment with 5\% EDTA solution for 2 hours. Three individuals were fixed at every time point.

\section{Results and Discussion}

Regardless of the experiment type the wound healing can be subdivided into three stages according to the in vivo observations: 1) the alignment of the wound edges (0-6 hpo $), 2)$ the regenerative membrane formation (6-24 hpo), and 3 ) the restoration of the body wall intact structure (4-5 days).

The complete wound healing occurs within 4-5 days post operation (dpo). The regeneration begins with the cleaning of the wound surface from the cell debris and broken spicules ending at 3 hpo. After that, the small irregularities of the wound edges which appeared due to the surgery gradually disappear and the wound edges become fairly smooth at $6 \mathrm{hpo}$ (Fig. 1A, D). At this stage, the continuous epithelium appears on the wound edges. It is formed by joining of the intact exopinacocytes and endopinacocyte arising from intact choanocytes near the wound edges through their transdifferentiation (Fig. 1G).

After the alignment of wound edges, the development of regenerative membrane begins. The regenerative membrane is a thin semitransparent two-layered cell membrane. It gradually covers the hole in the body wall or closes the opening in the basal part of the amputated oscular tube. The regenerative membrane grows from the periphery of the wound to its center. The development of the membrane occurs quickly: the regenerative membrane closes a part of the wound at $12 \mathrm{hpo}$, and it completely closes wound at 24 hpo in the majority of the experiments (Fig. 1B, E).

The epithelial morphogenesis plays the main role during the development of the regenerative membrane. The regenerative membrane is formed due to the convergent spreading and 

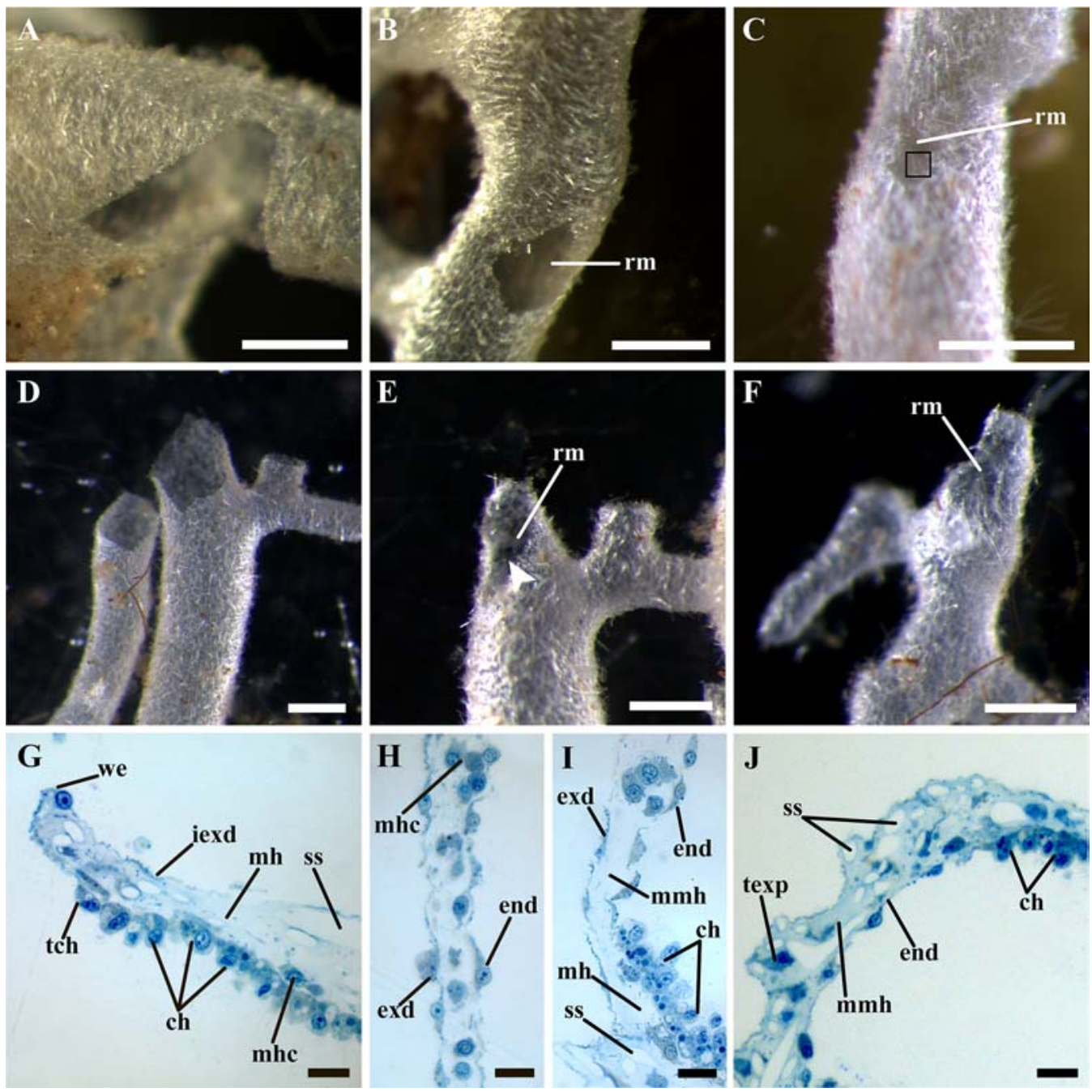

Fig. 1. The regeneration of the body wall and amputated oscular tubes in Leucosolenia complicata. A-C the regeneration of the body wall, D-F - the regeneration of the amputated oscular tube, G-J - the histological structure of the different stages of the regeneration. A - the alignment of the wound edges, 6 hours post operation (hpo); B - regenerative membrane completely closing the wound, $24 \mathrm{hpo}$; $\mathrm{C}$ - the restoration of the body wall intact structure in the wound area, 72 hpo, black square indicates the newly formed spicules in the regenerative membrane; D - the alignment of the wound edges, 6 hpo; E incomplete regenerative membrane closing a part of the wound, $24 \mathrm{hpo}$, white arrowhead indicates the hollow in the central part of the membrane; $\mathrm{F}$ - the regenerative membrane bearing numerous spicules, 72 hpo; $\mathrm{G}$ - the wound edge during its alignment, $6 \mathrm{hpo} ; \mathrm{H}$ - the regeneration membrane, 24 hpo; I - the transition zone between intact tissue near the wound and regenerative membrane, $24 \mathrm{hpo} ; \mathrm{J}$ - the restoration of the body wall intact structure, 96 hpo.

Abbreviations: ch - choanocytes; end - endopinacoderm of the regenerative membrane; exd - exopinacoderm of the regenerative membrane; iexd — intact exopinacoderm; $\mathrm{mh}$ - intact mesohyl; mhc — mesohyl cell; $\mathrm{mmh}$ — mesohyl of the regenerative membrane; $\mathrm{rm}$ - regenerative membrane; ss — space from removed spicule; tch — transdifferentiating choanocyte; texp - T-shaped exopinacocyte; we — wound edge. Scale bars: A-F $-500 \mu \mathrm{m}$; G-J $-10 \mu \mathrm{m}$.

Рис. 1. Регенерация стенки тела и отрезанных оскулярных трубок Leucosolenia complicata. A-C Ï регенерация стенки тела, D-F - регенерация отрезанной оскулярной трубки, $\mathrm{G}-\mathrm{J}$ - гистологическое строение различных стадий регенерации. А — выравнивание краев раны, 6 часов после операции 
fusion of epithelial layers: the exopinacoderm on the external side of the membrane and the endopinacoderm - on the internal. The formation of the endopinacoderm is most likely occurs due to the transdifferentiation of the choanocytes near the wound edges into endopinacocytes through their flattening and losing of flagellum and microvilli collar (Fig. 1G). Thus, at this stage, the regenerative membrane consists of two epithelial layers (exo- and endopinacoderm) and the thin mesohyl between them (Fig. 1H, J). The mesohyl of the membrane differs from intact one - it contains fewer cells, less abundant ECM (as it does not acquire staining on the histological sections like the ECM in the intact mesohyl near the wound edges) and lacks spicules (Fig. 1H, J).

Such a rapid formation of the regenerative membrane, in our opinion, is associated with the necessity to restore the normal water flow through the aquiferous system of the sponge as soon as possible. Probably, the appearance of a large opening in the body wall during the experiments significantly changes the water flow in the aquiferous system of the asconoid sponge, since large volumes of the water may be inhaled and exhaled from the animal's body through the wound opening rather than through the osculum and ostia. The formation of the regenerative membrane quickly returns the process of water pumping to the normal mode.

After the full development of the regenerative membrane, the restoration of the intact structure of the body wall proceeds. By 36-48 hpo, the wound size decreases, apparently, due to a decrease in the regenerative membrane area. By $72 \mathrm{hpo}$, the wound surface further decreases in size and, in some cases, becomes poorly discernible. The mesohyl of the regenerative membrane obtains intact structure - the cells become more abundant and spaces between them occupy by ECM (Fig. 1J). In addition, at this stage the new spicules appear in the regenerative membrane (Fig. 1C, F). These spicules can be formed either directly in the regenerative membrane. The elucidation of the source of the new spicules requires further studies.

Leucosolenia complicata has been successfully used for in vivo and histological studies of regeneration by some authors (Jones, 1957; Korotkova, 1961, 1969). Our results confirm previous descriptions concerning the main stages of body wall regeneration. As in previous descriptions, we showed that the wound healing occurs by the formation of the regenerative membrane (Jones (1957) called this structure as "healing membrane").

The epithelial morphogenesis, mainly spreading (flattening) and fusion of epithelial sheets is involved in the reparative regeneration in $L$. complicata. These processes are accompanied by transdifferentiation of choanocytes to endopinacocytes. Epithelial-mesenchymal transitions are absent during $L$. complicata regeneration. Moreover, we cannot reveal any morphologically distinct pluripotent cell types in this species. Therefore, regeneration in Leucosolenia has a mode in which lost body parts are replaced by the remodeling of the remaining tissue. Similar mechanisms of regeneration were described in other calcarean sponges Sycon lingua and S. ciliatum (Korotkova, 1972; Laplant et al., 2014).

(чпо); В — регенеративная мембрана, полностью закрывающая рану, 24 чпо; С - восстановление интактной структуры стенки тела в области раны, 72 чпо, черный квадрат отмечает новые спикулы в регенеративной мембране; D - выравнивание краев раны, 6 чпо; E - неполная регенеративная мембрана, 24 чпо, белая стрелка указывает на отверстие в центральной части регенеративной мембраны; F — регенеративная мембрана со множеством спикул, 72 чпо; G — край раны во время его выравнивания, 6 чпо; H - регенеративная мембрана, 24 чпо; I - переходная зона между интактными тканями вблизи раны и регенеративной мембраной, 24 чпо; J - восстановление исходной структуры стенки тела, 96 чпо.

Обозначения: ch - хоаноциты; end - эндопинакодерма регенеративной мембраны; ехd - экзопинакодерма регенеративной мембраны; iexd - интактная экзопинакодерма; mh - интактный мезохил; mhс — клетка мезохила; mmh — мезохил регенеративной мембраны; rm — регенеративная мембрана; ss — пространство от вытравленной спикулы; tch — трансдифференцирующийся хоаноцит; texp — T-образный экзопинакоцит; wе край раны. Масштаб: A-F - $500 \mu \mathrm{m} ; \mathrm{G}-\mathrm{J}-10 \mu \mathrm{m}$. 
The epithelial nature of the regeneration in Leucosolenia makes it similar to the regeneration in homoscleromorphs sponges, which was described in detail in Oscarella (Ereskovsky et al., 2015), and Eumetazoans, like Hydra, and to the last phase of the regeneration in the triploblastic animals (Salvenmoser et al., 2001; Galliot, Ghila 2010). In contrasts with Calcarea, Homoscleromorpha is notably the only sponge group to possess morphologically distinct basement membrane and specialized cell junctions and is therefore considered to possess true epithelia. The consequence of this peculiar organization is the predominance of epithelial morphogenesis during ontogenesis regeneration include, of these sponges (Ereskovsky et al., 2015).

In order to understand whether there is a correlation between the dominance of the epithelial morphogenesis during Leucosolenia regeneration and the peculiarity of their epithelial layers (choanoderm and pinacoderm), further studies using electron microscopy and molecular biology is necessary.

Knowledge on morphological basis of morphogenesis during Leucosolenia regeneration could have important implications for our understanding of the diversity and evolution of the regeneration mechanisms in metazoans and provides a strong basis for the future investigations with the genetic approaches.

\section{Acknowledgements}

Financial support by Russian Foundation for Basic Research \#16-04-00084 and the Russian Science Foundation \#17-14-01089 (for the microscopy) is gratefully acknowledged.

\section{References}

Alexander B.E., Achlatis M., Osinga R., Van der Geest H.G., Cleutjens J.P.M., Schutte B., de Goeij J.M. 2015. Cell kinetics during regeneration in the sponge Halisarca caerulea: how local is the response to tissue damage? // PeerJ. Vol.3. e820.

Ayling A.L. 1983. Growth and regeneration rates in thinly encrusting demospongiae from temperate waters // Biol. Bull. Vol.165. P.343-352.

Borisenko I.E., Adamska M., Tokina D.B., Ereskovsky A.V. 2015. Transdifferentiation is a driving force of regeneration in Halisarca dujardini (Demospongiae, Porifera) // PeerJ. Vol.3. e1211.

Ereskovsky A.V., Borisenko I.E., Lapebie P., Gazave E., Tokina D.B., Borchiellini C. 2015. Oscarella lobularis (Homoscleromorpha, Porifera) regeneration: Epithelial morphogenesis and metaplasia // PlosOne. Vol.10. e0134566.

Galliot B., Ghila L. 2010. Cell plasticity in homeostasis and regeneration // Mol. Reprod. Dev. Vol.77. P. 83755.

Jones W.C. 1957. The contractility and healing behavior of pieces of Leucosolenia complicata // Quart. J. Micr. Sci. Vol.98. P.203-217.

Korotkova G.P. 1961. Regeneration and somatic embryogenesis in the calcareous sponge Leucosolenia complicata Mont. // Acta Biol. Hung. Vol.2. P.315-334.

Korotkova G.P. 1969. [The peculiarities of morphogenesis during the development of the calcareous sponge Leucosolenia complicata Montagu from the small fragments of body wall]// Vest. Leningr. Univ. Vol.15. P.15-22 [in Russian, with English summary].

Korotkova G.P. 1972. [Comparative morphological investigations of development of sponges from dissociated cells] // Trans. Leningr. Soc. Natur. Vol.78. P.74-109 [in Russian, with English summary].

Korotkova G.P. 1997. [Regeneration in animals]. SaintPetersburg: Saint-Petersburg University Press. 297p. [in Russian, with English summary].

Laplante M., Adamska M., Leininger S., Ereskovsky A. 2014. Sycon ciliatum (Calcarea, Calcaronea) regeneration peculiarities [abstract] // 5th meeting of the European Society for Evolutionary Developmental Biology 22-25 July 2014, Program and Abstracts: Vienna, Austria, 2014. P.374-375.

Lavrov A.I., Kosevich I.A. 2016. Sponge cell reaggregation: cellular structure and morphogenetic potencies of multicellular aggregates // J. Exp. Zool. A. Ecol. Genet. Physiol. Vol.325. P.158-177.

Luter H.M., Whalen S., Webster N.S. 2012. The marine sponge Ianthella basta can recover from stress-induced tissue regression // Hydrobiologia. Vol.687. P.227-235.

Millonig G. 1964. Study on the factors which influence preservation of fine structure // Sympos. on electron microscopy. Rome, Italy: Consiglio Nazionale delle Ricerche. P.347.

Rapp H.T. 2015. A monograph of the calcareous sponges (Porifera, Calcarea) of Greenland // JMBA. Vol.95. P.1395-1459.

Salvenmoser W., Riedl D., Ladurner P., Rieger R. 2001. Early steps in the regeneration of the musculature in Macrostomum sp. (Macrostomorpha) // Belg. J. Zool. Vol.131. P.105-109.

Wulff J. 2013. Recovery of sponges after extreme mortality events: morphological and taxonomic patterns in regeneration versus recruitment// Integr. Comar. Biol. Vol.53. P.512-523.

Responsible editor E.N. Temereva 